w liturgii niebieskiej. Wieczornej modlitwie przewodniczył i wygłosił homilię rektor Sląskiego Seminarium Duchownego z Katowic - ks. dr Stefan Cichy.

W Sesji wzięli udział członkowie Polskiego Towarzystwa Teologicznego, alumni Krakowskiego Seminarium Duchownego, a także alumni z sèminariów zakonnych, szczególnie liczny udział wzięli klerycy OO. Franciszkanów, którzy wraz z alumnami krakowskimi przygotowali liturgię tej wspólnotowej modlitwy Kościoła. Uczestnikami tego spotkania byli następnie słuchacze Sekcji Teologicznej Instytutu Liturgicznego oraz członkowie Międzyseminaryjnego Koła Liturgicznego, które założył i od lat prowadzi Kierownik Katedry Teologii Liturgii i Dyrektor Instytutu Liturgicznego [ - - - ] [Ustawa $\mathrm{z}$ dn. 31 VII 1981. O kontroli publikacji i widowisk art. 2 pkt. 6 (Dz. U. nr 20, poz. 99, zm. 1983 Dz. U. nr 44, poz. 204)] ks. prof. dr hab. Wacław Świerzawski. W przygotowaniu tej sesji miała też swój wkład Sekcja Sztuki Liturgicznej na Instytucie Liturgicznym, jeden z jej pracowników, artysta malarz Zbigniew Gizella wykonał portret Ks. Prof. W. Schenka, który umieszczony był obok stołu prezydialnego. Obradom sesji przewodniczył kierownik Seekcji Biblijno-Liturgicznej ks. dr Jelonek. Prelegentów gościnnie podjąl rektor Krakowskiego Seminarium Duchownego - ks. dr Stanisław Nowak.

Wspominając na tej Sesji postać zmarłego Liturgisty, ks. doc. J. ChmieI wyliczył trzy środowiska, w których żył on i działał: była to mianowicie najpierw ziemia rodzinna - Sląsk, potem był KUL - środowisko nauki i wreszcie był Kraków, miasto z wyboru, z miłości. Właśnie ta sesja nie była sympozjum ściśle naukowym o zasięgu ogólnopolskim, ale pragnęła być po prostu skromnym wyrazem czci, wdzięczności za serce, którym darzył Kraków, jego historię, jego świętych, za serce, którym darzył Papieski Wydział Teologiczny, a w nim przede wszystkim młodzież studiująca, alumnów przygotowujących się do sprawowania żywej liturgii wśród Ludu Kościoła krakowskiego.

Kraków

KS. STEFAN KOPEREK CR

\begin{tabular}{lllllllllll}
$\mathbf{A}$ & $\mathbf{R}$ & $\mathbf{C}$ & $\mathrm{H}$ & $\mathbf{I}$ & $\mathbf{W}$ & $\mathbf{A}$ & $\mathbf{L}$ & $\mathbf{I}$ & $\mathbf{A}$ \\
\hline
\end{tabular}

\title{
Z ARCHIWUM LITURGISTOW \\ KILKA MYŚLI O RUCHU LITURGICZNYM (1951 R.)
}

Wszyscy rozumieją, że nie ma dziś rzeczy pilniejszej jak postawienie na należytym poziomie pracy w Kościele. Inne placówki pracy już w dużym stopniu straciliśmy. Zostały nam rzeczy najistotniejsze.

Jeżeli jednak tak jest, to będzie karygodnym zaniedbaniem, jeżeli nabożeństwa nasze nie dadzą tego, co dać mogą, jeżeli skarby łaski i prawdy w nich zawarte pozostaną nadal w dużej mierze 
ukryte i niedostępne dla wiernych. Jest krytyczna godzina, pięć przed dwunastą i duszpasterze, którzy w tak krytycznym momencie zaniedbają tak wielkie możliwości, będą musieli ponieść odpowiedzialność przed Panem Bogiem.

Słuszność założeń i celów ruchu liturgicznego nie ulega żadnej wątpliwości. Chodzi o udostępnienie wiernym życia z Chrystusem żyjącym i działającym w Kościele, chodzi o oparcie ich życia o Sakrament $w$ sensie najszerszym, o wprowadzenie ich $w$ tajemnicę Ciała Chrystusowego, którego członkami sa jak bardzo nieraz nieświadomie. Chodzi o otworzenie, ich wyschniętych brakiem prawdy duszom, źródeł-najczystszych liturgii i Pisma Swiętego.

Przyznaje się, że ruch liturgiczny, jak zresztą kazda inna metoda apostolska, popełnia błędy, przyznaje się, że niektóre realizacje, zbyt powierzchowne i na samej formie oparte, albo zbyt szybkie i gwałtowne, albo cząstkowe i na jakiś szczegół zbytnio skoncentrowane (np. śpiew, albo Msza św. recytowana jako magiczny środek), mogły sprawic w duszach pewne szkody i spowodować pewne opory w społeczeństwie, ale najwyższy czas zrozumieć, że zarzuty nie dotyczą istoty rzeczy i trzeba wreszcie umieć nad nimi przejść i spojrzeć na rzecz w prawdzie.

Słúszność zasadniczych postulatów ruchu liturgicznego nie podlega żadnej dyskusji. Nie mogą tu decydować jako argumenty jakieś niekorzystne doświadczenia $\mathrm{z}$ terenu, bo to nie sprawa doświadczenia, ale wiary.

Jeżeli się komu zdaje, że zastosowanie metod ruchu liturgicznego wypędzi ludzi z kościoła, to prawdopodobnie ma na myśli nieprawidłowe ich zastosowanie. A jeżeliby nawet prawidłowe ich przeprowadzenie spowodowało w pierwszym etapie odejście kilku procent, których większość powróci później, to jeszcze nie stanowi argumentu przeciw nim.

Żeby pojąc jak palącą jest sprawa, trzeba sobie uświadomić, że chwila w której żyjemy jest przełomowa. W tej chwili caly naród ulega pewnej ewolucji duchowej (w kierunku ratio) wobec której stare metody duszpasterskie, oparte na pewnej uczuciowości, coraz bardziej tracą na sile i przestają ludziom odpowiadać. Pełne kościoły bynajmniej nie są dowodem, że metody duszpasterskie, że nabożeństwa w ich formie obecnej naprawdę ludziom odpowiadają. Działają tu jeszcze stare rutyny, działa i uczuciowa pobożność spotęgowana cierpieniem, działa i instynkt łaski, ale właściwie duchowa łączność między ludem a treścią nabożeństw jest słaba i kierunek ewolucji każe przewidywać, że jeszcze osłabnie.

Dusze potrzebują teraz mocniej oprzeć się na prawdzie Chrystusowej, i jeżeli im tego nie damy, mogą odejść. Przedziwna niekonsekwencja czyniąca, że ludzie o światopoglądzie dalekim od katolicyzmu, trzymają się jednak uczuciowo Kościoła, będzie coraz rzad- 
sza. Człowiek dzisiejszy jest coraz mniej zdolny do niekonsekwencjii, coraz bardziej niecierpliwy wobec form, które nie mają dlań treści. Coraz częściej też od nich odchodzi. Jeżeli więc metody ruchu liturgicznego mogą przy pierwszym uderzeniu parę osób zrazić, które normalnie później powinny wrócić, to zaniedbanie tych nowych dróg i pozostanie przy dawnych indywidualistycznych metodach może naprawdę doprowadzić do katastrofy wyludnienia naszych kościołów. Nie należy sobie robić zbytnich iluzji. Będzie to usunięcie ludzi z kościoła w sposób niegwałtowny, ale bardziej jeszcze radykalny i trudny do naprawienia z powodu laicyzacji mentalności. Szuka się zbawienia poszczególnych dusz, a społeczność chrześcijańska jako taka, świadoma siebie, przestaje istnieć (Niema Civitas Dei, która łączy się całkowicie z liturgią).

Dziś w Polsce metoda liturgiczna może jeszcze zaważyć decydująco. We Francji już za późno na nią, już ona nie wystarcza, bo kościoły świecą pustkami. Ale i u nas zabrnęliśmy daleko w świeckość i laicyzm, jeżeli w nasze życie nie wpuścimy więcej Lumen Christi, to nie zrobimy nic. Mamy w Polsce, wielu misjonarzy zdolnych poruszyć lud i doprowadzić do szczerej skruchy, ale czemu przypisać, że po misjach wracają tak rychło stare grzechy. Oto brak pozytywnej strony, brak światła. Dusza robi postanowienia, chce się poprawić, ale nie ma na czym się oprzeć, brak jej tej cudownej wizji Pawłowej, tej radości zbawienia w Chrystusie, tego paschalnego ducha, w którym jest nadprzyrodzona moc ku zwycięstwu, brak jej po prostu wiary.

Nacisk na samą miłość w dzisiejszym wychowaniu, połączony z zaniedbaniem rozwoju wiary, prowadzi do rozbratu między wiarą a miłością, kształtuje typy słabe o dobrym sercu ale o umysłowości zatrutej błędem, nieśmiałe wobec świata, trzymające się Boga bardziej kurczowo niż świadomie, z przekonania. Nawet częsta Komunia nie wystarcza, gdy się $z$ tym Chrystusem nie nawiąże kontaktu przez słowo prawdy, które jest jednym z głównych kanałów łaski. Chrystus musi do nas przemawiać i oczyszczać nas prawdą swoją, inaczej wpadamy w ciemność i bezład pomimo sakramentów i pomimo szarpania się woli ku dobremu. Dlatego też Kościól nie pozwala składać Najświętszej Ofiary bez Mszy katechumenów, tzn. bez słowa prawdy, które karmi wiarę. Lekarstwem na ten katastrofalny brak światła, nie jest $w$ pierwszym rzędzie tomizm, pomimo jego ogromnych walorów, ale Ewangelia i to Ewangelia poznawana w rozmodleniu, w świętej liturgicznej akcji.

Chodzi o inicjatywe, to znaczy o wprowadzenie, wtajemniczenie w Mysterium Christi, bo wylecieliśmy z jego łona w ,ciemności zewnętrzne" i dlatego jest „płacz i zgrzytanie zębów”.

Chodzi więc nam nie o jakieś nowe chwyty duszpasterskie, ale o system wychowawczy totalny, do gruntu nadprzyrodzony, działający na całego człowieka i całego człowieka ratujący. 
Są różne metody w Kościele (np. kazania stanowe, rekolekcje, organizacje itp.) ale jest jedna Metoda Kościoła.

Tą Metodą Kościoła jest samo życie Kościoła i jego kult liturgiczny. Różne inne metody są dobre, ale jest w nich zawsze coś cząstkowego i coś zbyt przyrodzonego, by zwyciężyć siłę laicyzmu, pewna systematyka ludzi. Inaczej Metoda Kościoła w liturgii. Ona chwyta całego człowieka: społecznie i indywidualnie, duchowo i cieleśnie, aktualizując w nim jednocześnie i modlitwe i czyn. Wszystko to jednocześnie harmonijnie, stopniowo, powodując asymilację nie systematyczną jak w szkole, ale życiowa i głęboką, jak dziecko przyjmuje wychowanie domowe.

\section{SZKIC METODY \\ Zasady i wytyczne.}

\section{Z Chrystusem w Kościele.}

Z a s a d a: Złączyć się z Chrystusem żyjącym w Kościele, wykorzystując maksymalnie trzy środki:

Msze św.,

Sakramenty,

Rok Kościelny.

2. Powrót do źródeł.

Sięgnąc śmiało i obficie do źródeł. Kapłan winien dawać to, czym sam żyje, a przynajmniej żyć powinien. (Brewiarz, mszał, Pismo św., Ojcowie Kościoła i inni święci). Nie szukać ciekawych wzniosłych aplikacji duchowych indywidualnych, ale raczej po prostu pokazywać, co w słowie Bożym JEST, czego Bóg naucza, co objawia, czego żąda, co obiecuje. Aplikacje do życia jak najbardziej bezpośrednie, wracając wciąż do Chrystusa i Jego życia w Kościele.

Po niedługim czasie przekona się kapłan, jak nieocenione skarby sam posiada i coraz bardziej będzie pragnął ich udzielać. Również i wierni spostrzegą, że życie w Kościele jest ciekawe, głębokie, i że każdy tydzień przynosi treści nowe, piękne, pociągające. Dotychczasowe nabożeństwa były strasznie jednostajne, nudne: Msza św. bez żywego udziału, bez wyjaśnienia tekstów, zawsze taka sama. Nabożeństwa wieczorne składające się ze stereotypowej litanii, czy cząstki różańca. Idzie się z obowiązku czy z pobożności, ale tak ważny czynnik zainteresowania zupełnie nie istnieje. Nabożeństwa są wręcz nudne. Stąd pewna dewiacja w duszpasterstwie, polegająca na wprowadzaniu różnych. elementów wątpliwej wartości, celem zainteresowania i pociągnięcia ludzi: kina parafialne, piłki parafialne itd. wszystko tak przeciwne dawnym metodom Kościoła, a przeciwnie charak- 
terystyczne dla metod poganizmu (Panem et circenses). Zdrowy Chrystianizm musi pociągać swą własną treścią i to jest do osiągnięcia, trzeba tylko tą treść pokazać.

W kościele powinny być co dzień nabożeństwa rano i wieczór. Rano Msza św. z objaśnieniami, homilią, czynnym udziałem, wieczorem modlitwy z psalmami, czytaniami, śpiewem, homilią itd. pomału światło Boże będzie oświecało duszę i będą się przemieniać. Kto w to nie wierzy, nie wierzy w Chrystusa i nie wierzy słowom Apostoła: Evangelium virtus Dei in salutem omni credenti. Zamiast zdać się na przemieniającą siłę. Prawdy nieustannie w swym źródle okazywanej, jesteśmy wciąż w gorączkowym poszukiwaniu nowych chwytów wstrząsających uczuciem, wywołujących nastroje wybujałe, ale krótkotrwałe, i na systemie nerwowym więcej niż na asymilacji prawdy oparte. Czasem i elektroszoki są potrzebne, ale nie moga one zastąpić zwykłego odżywiania. Dusza potrzebuje obfitego, codziennego, spokojnego adżywiania czystą obiektywną prawdą objawioną, i to jej trzeba dać.

To elementarna zasada higieny życia kościelnego.

Metoda ta ma jeszcze drugą bardzo istotna zaletę, a mianowicie, że formuje samego kapłana. Tragiczny konflikt między pracą duszpasterską a wyrobienie osobistym przestaje istnieć, (kapłani wyschnięci, spłyceni). Wyrobienie i pogłębienie kapłana idzie po tej samej linii co i jego praca duszpasterska w atmosferze wielkiego pokoju.

Będzie kapłan miał więcej czasu, nie będzie potrzebował rozdrabniać się na pracę $w$ małych zespołach. Przez samą pracę kościelną naprawdę pogłębioną wyrobi sobie współpracowników, którzy go chętnie i skutecznie gdzie indziej zastąpią. Dosięgnie i wszystkich razem i każdego pojedynczego głębiej niż innymi metodami, bo wszyscy poznają, że są Kościołem Chrystusowym. Prawdziwie metoda Tego, który nie chciał nam apostolstwa zbyt ciężkim czynić, ale obiecał, że brzemię Jego lekkim będzie. Myśmy je sobie uczynili nieznośnym i morderczym dla duchowego życia kapłanów, a więc zasada: Verbum Christi inhabitet in vobis abundater (por. 1 Kor 3, 16).

\section{Zasada stopniowania.}

Nie można natychmiastowo wprowadzać wszystkich form liturgicznych, ale powoli, tak jednak, by od samego początku wierni mogli korzystać z dobrodziejstw życia z Kościołem, z bogactwa tekstów, z świadomością swego udziału w życiu obecnego i działającego wśród nich Chrystusa. Poza tym jednak musi być stosowana metoda ostrożnej ewolucji, aby nowe elementy były zawsze przygotowane przez stare i żeby nie było niebezpiecznych przeskoków.

Każdy krok naprzód, każde wyelliminowanie jakiegoś niepożądanego elementu, musi być dobrze wytłumaczone i zrozumiane. Nie pu- 
rytańska eliminacja jako zasada, ale maksymalne wykorzystanie istniejących elementów ludowych. Np. przestudiować znane pieśni ludowe, których lud zna zazwyczaj pierwsze zwrotki i wykorzystać najpiękniejsze dalsze zwrotki do różnych części Mszy św. czy innych nabożeństw. Wykorzystać Kyrie eleison i Agnus Dei z litanii, by śpiewać w czasie Mszy św. itd. wciąż uzupełniając przez uczenie nowych rzeczy.

W szystko na dalszą metę...

Ale przede wszystkim uczyć, uczyć, uczyć.

Można wejść i na 16 piętro, ale nie po ścianie lub po rynnie, lecz po stopniach.

Msza św. gregoriańska według Motu Proprio, zostaje ideałem, do którego zmierzamy, ale nie jako formy jedynej. Msze ciche, recytowane na różne sposoby, ze śpiewem i bez śpiewu, pozostawiają większą swobodę działania. Co zaś do Mszy śpiewanej, to wydaje się, że używanie śpiewów ludowych nie stanowi wykroczenia przeciw przepisom Niotu Proprio, które jakkolwiek expressis verbis wyklucza przeciwne zwyczaje, to jednak nie zawiera klauzuli „etiam centenaria vel speciali mentione digna", co byłoby chyba wymagane in hac materia przez zasadę kanonu 30 CJC. Zresztą dochodzi inna zasada, a mianowicie obawa o "scandalum populi" vel ,detrimentum religionis" w którym to wypadku zachodzi nowe pojęcie "Consuetudo reprobata, tolerata" iudicia ordinarii - aż do czasu, gdy niebezpieczeństwo tego zgorszenia będzie zażegnane.

Zresztą ewolucja w całym Kościele zdaje się iść w kierunku przyjmowania do kultu liturgicznego pewnych elementów narodowych.

4. Hierarchia wartości.

Trzeba ją nieustannie wpajać. A więc niczego nie wykluczać, co jest chrześcijańskie, wszystko rozwijać, ale wszystko na swoim miejscu.

Tak więc Msza św., Sakramenty najważniejsze, ale inne nabożeństwa też ważne. Modlitwa publiczna nie może zabić prywatnej itd. (Kult Przenajśw. Sakramentu, kult Maryi).

Wszystko w życiu kapłana i wiernego ma być na swoim miejscu. Wykluczyć to, co niechrześcijańskie, hierarchicznie uporządkować wszystko inne.

5. Veritas semiologica.

Bardzo ważnym momentem wychowawczym kapłana i wiernych jest świadome dążenie do prawdy we wszystkim. Należy to czynić tym bardziej ostrożnie i stopniowo, im bardziej chodzi o rzeczy zewnętrzne i mniej istotne. W rzeczach zaś istotnych żelazna konsekwencja.

Kościół i ołtarz, służba kościelna, śpiew, sztuka, niech będą naprawdę tym, czym być mają. 
6. Zastosowanie starej pedagogiki Kościoła.

Ożywienie dynamiki nabożeństw przez wprowadzenie pewnego rytmu części stałych i zmiennych, umiejętne operowanie chwilami ciszy, refrenem, ruchami ciała, udziałem chóru, scholi, lektorów, diakonów itd.

7. Związanie $\mathrm{z}$ oltarzem.

Jako centrum wszelkich przejawów życia parafialnego np. Caritas, apostolstwo chorych - różne kolekty - organizacje... Bo oltarz jest miejscem spotkania człowieka z Bogiem, miejscem, gdzie czlowiek daje i otrzymuje, miejscem gdzie i nasza jedność w Chrystusie nasza rodzina parafialna tworzy się, utrzymuje i odnawia.

8. Praktyczne wprowadzenie.

Stosowane wytrwale na każdym kroku: Msza św., Nieszpory, Sakramenty, pogrzeby, sakramentalia, okresy liturgiczne, a nawet treść pieśni ludowych tłumaczyć, tłumaczyć, tłumaczyć.

Nie można się dziwić oporom ludu, gdy się mu nie wytłumaczy, ale gdy się wyjaśni, lud przyjm̄uje. Niech się księża wciąż nie tłumaczą oporami ludu, bo największe opory są właśnie ze strony samych księży.

9. Podkreślenie elementu społecznego.

Podkreślenie przy każdej okazji elementu społecznego, rodzinnego, parafialnego, kościelnego, wspólnoty w Chrystusie, aby dążyć do wytworzenia duszy jednej i myśli jednej w całej parafii.

Tak np. Msza św. jest ucztą ofiarną całej rodziny, chrzest powiększa rodzinę, czynny udział w nabożeństwie ją zespala i jest jej wyrazem. Operować pojęciami: ,nasi chorzy, nasza sprawa poziomu duchowego parafii, nasz sposób rozumienia np. małżeństwa, obowiązków życia rodzinnego itd." aby pomału dojść do stworzenia pewnej chrześcijańskiej opinii publicznej opartej na szlachetnej dumie z Chrystusa mieszkającego wśród nas i pragnieniu, by nie być Jego niegodnym.

10. Kontakt z ludem.

Wejście w lud ale bez demagogii, bez lekceważenia dystansu, który jest wychowawczy, i bez wprowadzania ludowładztwa i krytycyzmu, aby nie nadwyrężyć dyscypliny kościelnej. Kapłan nie zawsze $\mathrm{z}$ ambony przemawia, ale czasem $\mathrm{w}$ nawie, bardziej rodzinnie. Metodą św. Pawła publice et per domos. Nie rozdrabniać się jednak, nie tracić syntezy, kierować ku jedności w Kościele.

11. Styl nabożeństw ludowych, niech też czerpie natchnienie $z$ nabożeństw czysto liturgicznych w swym układzie, doborze tekstów, naukach itd. Wszystko łagodnie ku jedności. 
12. Okresowa zmienność nasilenia.

Zmiana tempa i nasilenia tej pracy aby nie znużyć. Np. Adwent, Post, intensywniej przerobić itp.

13. Wszechistronność stosowania tych zasad.

Zasady te stosowane zawsze i wszędzie, i do wszystkich (kapłan, organista, ministranci, zakonnice, wierni) bez niekonsekwencji, osiągną cel. Błędem liturgistów było często brak totalnej tezy, i rozwijanie jakiegoś jednego elementu, np. Msza recytowana, który miał automatycznie wpływać wychowawczo na lud. Niebezpieczna iluzja, która wielu do metody liturgicznej zraziła, bo spotkali się z tą metodą źle zastosowaną. Więcej niż w jakiejkolwiek innej, w tej metodzie poszczególne elementy nabierają znaczenia tylko w związku z całością, wszystkie się składają na jedną wielką, organiczną syntezę, która przyczynia się do rozbudzenia w wiernych jakby pewnej intuicji tej obiektywnej wielkości, w którą mają wejść całym swym życiem, a którą jest Mysterium Dei.

Metoda naszlicowana jest właściwie bardzo prosta. Nic w niej nie ma sztucznego, wszystko wynika z natury rzeczy. Opiera się cała na prostej wierze w siłę pociągającą i oczyszczającą i zbawiająca Chrystusa żyjącego w Kościele.

Wierzymy po prostu w skuteczność środków, jakie On ustanowił do zbawienia i w niezrównaną moc Jego Słowa tłumaczonego ludziom.

Zrobiwszy taki akt wiary, spokojnie pracujemy tak, by On mógł jak najswobodniej działać i nic więcej.

Jest to zastosowanie tej prostej formy z Dziejów Apostolskich: „Erant perseverantes in doctrina Apostolorum, et communicatione fractioni panis et orationibus".

$\mathrm{Na}$ tych trzech zasadniczych elementach:

Doktryna Apostolska

Sakrament,

Modlitwa

wszystko się opiera.

A więc nie chodzi przede wszystkim o spiew gregoriański, ani o recytacje itd.

Ale o inicjacje, czyli o wprowadzenie w TAJEMNICE CHRY STUSA. Szczegółowsze opracowanie tej metody i uprzystępnienie jej księżom byłoby jednym z zadań Ośrodka Apostolstwa Liturgicznego, o którym poniżej. 


\section{KILKA WNIOSKÓW}

1. Stworzenie pewnego centralnego Ośrodka dla spraw odnowienia liturgicznego, który by zespolił istniejące w kraju siły fachowe w celu niesienia pomocy duszpasterstwu.

Tego rodzaju centrala mogłaby oddać pewne usługi Kościołowi przez różnego rodzaju pracę $n p$.

Opracowanie przewodnika metodycznego do apostolstwa liturgicznego w parafii, przygotowanie tekstów niezbędnych do apostolstwa liturgicznego.

Projekty: Np. zorganizowanie życia liturgicznego w ugrupowaiach specjalnych, jak szkoły, seminaria, zakony...

Materiały: kazania ite.

2. Przy obsadzaniu parafii zwłaszcza $\mathbf{w}$ większych ośrodkach łączenie ze sobą duszpasterzy jednomyślnych, zdolnych do owocnej współpracy w wyżej naszkicowanym kierunku.

Tym duszpasterzom pozwolić, a nawet zachęcić ich, by codziennie rano i wieczorem urządzali nabożeństwa $z$ objaśnieniem obrzędów, tekstów liturgicznych i Pisma św. według zasad wspomnianych wyżej w punkcie drugim, umożliwiając wiernym czynny udział w tych nabożeństwach.

To narazie wystarczy. $\mathrm{Z}$ pomocą łaski Bożej kościoły te staną się ośrodkiem promieniowania, szkołami dla pracujących w nich kapłanów i przykładem dla innych duszpasterzy.

3. Najpilniejsza sprawa: wychowanie kleryków do życia z Kościolem. Zorganizowanie życia w Seminarium pod tym względem wzorowo (projekty do opracowania) to znaczy realizacji (syntetyczna i integralna).

Zgromadzeni Księża:

Ks. Prałat Stanisław Sprusiński (Warszawa)

Ks. Rektor Józef Grochocki (Pelplin)

Ks. Karol Konopka (Lublin)

Ks. Władysław Spikowski (Poznań)

Ks. Alfons Przybyła (Chorzów)

Ks. Wacław Szenk (Nysa)

Ks. Witold Pietkun. (Éódź)

Ks. Karol Wojtyła (Kraków)

O. Piotr Rostworowski (Tyniec)

Z całą pokorą poddają te myśli i wnioski pod sąd Najdostojniejszego Księdza Prymása Polski. 